\title{
Identification of Interactions of ABT-341 to Dipeptidyl Peptidase IV during Molecular Dynamics Simulations
}

\section{(Identifikasi Interaksi-interaksi ABT-341 dengan Dipeptidil Peptidase IV pada Simulasi Dinamika Molekul)}

\author{
Enade Perdana Istyastono*, Michael Raharja Gani \\ Fakultas Farmasi, Universitas Sanata Dharma, Yogyakarta, Indonesia.
}

*E-mail: enade@usd.ac.id

Article Info:

Received: 24 May 2021

in revised form: 9 July 2021

Accepted: 30 July 2021

Available Online: 1 October 2021

Keywords:

Dipeptidyl Peptidase IV (DPP-IV)

YASARA-Structure

Molecular Dynamics

PyPLIF HIPPOS

Corresponding Author:

Enade Perdana Istyastono

Fakultas Farmasi

Universitas Sanata Dharma

Kampus 3 Paingan Maguwoharjo

Depok Sleman Yogyakarta 55282

Indonesia

email: enade@usd.ac.id

\begin{abstract}
Background: Dipeptidyl Peptidase IV (DPP-IV) is an established drug discovery target for type 2 diabetes mellitus (T2DM) therapy. On the other hand, molecular dynamics (MD) simulations have been widely employed to obtain insights of the protein-ligand interactions in structure-based drug design research projects. Moreover, a software to identify protein-ligand interactions called PyPLIF HIPPOS was made publicly available recently. Employing PyPLIF HIPPOS to identify the interactions of DPP-IV and its ligand ABT-341 during MD simulations was then of considerable interest. Objectives: The main aim of this study was to identify protein-ligand interactions of ABT-341 to DPP-IV during MD simulations. Material and Methods: The crystal structure of DPP-IV co-crystallized with ABT-341 obtained from the Protein Data Bank with code of 2I78 was used as the main material. YASARA-Structure was employed for performing $10 \mathrm{~ns}$ prodution run MD simulations with snapshots in every 100 ps and PyPLIF HIPPOS was used to identify the protein-ligand interactions. Results: There were 23 interactions involving 13 residues identified by employing PyPLIF HIPPOS during the MD simulations. Two of them identified in all snapshots, i.e., hydrophobic interactions to PHE357 and TYR666. Conclusions: PyPLIF HIPPOS was succesfully employed to identify the interactions of ABT-341 to DPP-IV during MD simulations.
\end{abstract}




\begin{abstract}
ABSTRAK
Latar Belakang: Dipeptidil Peptidase IV (DPP-IV) merupakan target penemuan obat untuk terapi diabetes tipe 2 yang sudah terbukti. Di lain pihak, simulasi dinamika molekul sudah dimanfaatkan secara luas untuk memperoleh wawasan mendalam terkait interaksi-interaksi protein-ligan dalam proyek-proyek penelitian rancangan obat berbasis struktur. Baru-baru ini, sebuah program komputer untuk identifikasi interaksi-interaksi protein-ligan bernama PyPLIF HIPPOS dipublikasikan dan dapat diakses masyarakat secara gratis. Pada penelitian yang dipaparkan pada artikel ini, PyPLIF HIPPOS dimanfaatkan untuk mengidentifikasi interaksiinteraksi DPP-IV dengan ligannya ABT-341 pada simulasi dinamika molekul. Tujuan: Penelitian ini bertujuan untuk mengidentifikasi interaksi-interaksi ABT-341 dengan DPP-IV pada simulasi dinamika molekul. Bahan dan Metode: Struktur kristal DPP-IV dengan ligan ko-kristal ABT-341 dengan dari Protein Data Bank kode 2 I78 digunakan sebagai bahan utama. Simulasi dinamika molekul $10 \mathrm{~ns}$ production run dengan pengambilan snapshot setiap 100 ps dilakukan menggunakan YASARA-Structure. PyPLIF HIPPOS digunakan untuk identifikasi interaksi-interaksi protein-ligan pada penelitian ini. Hasil: Didapati 23 interaksi dengan melibatkan 13 residu asam amino selama simulasi dinamika molekul. Dua dari interaksi yang teridentifikasi terdapat pada semua snapshot, yaitu interaksi hidrofobik dengan PHE357 dan TYR666. Kesimpulan: PyPLIF HIPPOS terbukti sukses mengidentifikasi interaksi-interaksi antara ABT-341 dan DPP-IV dalam simulasi dinamika molekul.
\end{abstract}

Kata kunci: Dipeptidil Peptidase IV (DPP-IV); YASARA-Structure; Dinamika Molekul; PyPLIF HIPPOS.

\title{
INTRODUCTION
}

Diabetes mellitus has become one of major global health problems (Guariguata et al., 2014; Zheng, Ley, \& Hu, 2018). More than $90 \%$ of the diabetes mellitus cases are type 2 diabetes mellitus (T2DM) and the complications of this T2DM reduces significantly the quality of life of most patients (Zheng et al., 2018). The most recent stategy in the T2DM therapy is the usage of Dipeptidyl Peptidase IV (DPPIV) inhibitors (Agrawal, Gautam, Pursnani, \& Maheshwari, 2018; Wang, Sun, Sang, Liu, \& Liang, 2018). There are at least six drugs targeting DPP-IV available in the market for T2DM treatment, i.e., Vildagliptin, Sitagliptin, Linagliptin, Saxagliptin, Gemigliptin, and Teneligliptin (Agrawal et al., 2018). Discovery of novel DPP-IV inhibitors is therefore of considerable interest. Interestingly, recent publications report some natural products as potential DPP-IV inhibitors (Li et al., 2018), e.g., berberine (Al-Masri, Mohammad, \& Tahaa, 2009), and flavonoids (Fan, Johnson, Lila, Yousef, \& De Mejia, 2013; Li et al., 2018). Insights from examining the interactions of these compounds to DPP-IV could be beneficial in further drug discovery and development for the therapy of T2DM (Fan et al., 2013).

Molecular dynamics (MD) simulations have become a prominent method to study the movement and atomic interactions of protein and ligand atoms overtime (Hollingsworth \& Dror, 2018). A potent competitive ligand will stabilize the protein-ligand interactions in the binding pocket which, in turn stabilizes the structure of of the whole protein. The stability of the ligand binding modes to the protein could be then examined in MD simulations for 10 ns production run (Liu, Watanabe, \& Kokubo, 2017). The ligand binding modes to the proteins are considered stable if the deviation of the rootmean-square deviation (RMSD) of the backbone atoms of the protein in the last $5 \mathrm{~ns}$ of the MD 
simulations is less than $2 \AA$ (Liu et al., 2017). It is then of considerable interest to obtain insights of the protein-ligand interactions from the stable ligand binding modes. On the other hand, a software to identify interactions from a protein-ligand complex named PyPLIF HIPPOS was made publicly available recently (Enade P. Istyastono, Radifar, Yuniarti, Prasasty, \& Mungkasi, 2020; Enade P Istyastono, Yuniarti, Prasasty, \& Mungkasi, 2021). The availability of PyPLIF HIPPOS offers possibilities to identify protein-ligand interactions from snapshots of MD simulations, which then could be employed to combine the lock-and-key theory and the induced-fit theory in computer-aided drug discovery research project.

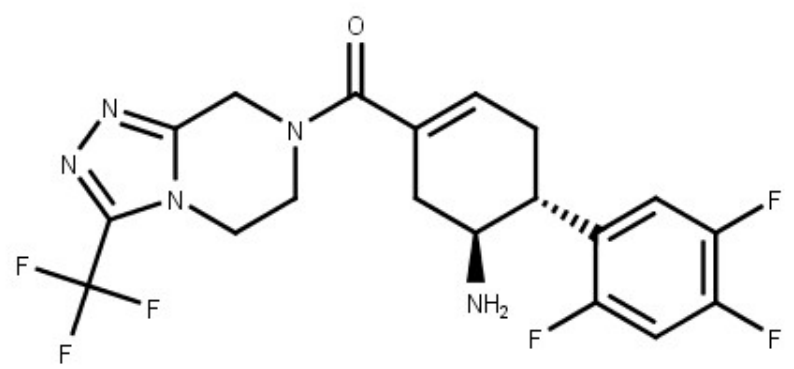

Figure 1. Structure of (1S,6R)-3-\{[3-(trifluoromethyl)-5,6-dihydro[1,2,4]triazolo[4,3-a]pyrazin-7(8H)yl]carbonyl\}-6-(2,4,5-trifluorophenyl)cyclohex-3-en-1-amine (ABT-341).

Aimed to identify protein-ligand interactions of the complex DPP-IV and ABT-341 (Figure 1) in order to obtain insights for further discovery projects, the research presented in this article performed short MD simulations for $10 \mathrm{~ns}$ production run of the complex using YASARA-Structure followed by employing PyPLIF HIPPOS to identify protein-ligand interactions of the snapshors of the last $5 \mathrm{~ns}$ of the MD simulations. The results showed that ABT-341 stabilized DPP-IV, and hydrophobic interactions of ABT-341 to Phe357 and Tyr666 were identified as the conserved interactions during the MD simulations.

\section{MATERIAL AND METHODS}

\section{Materials}

The crystal structure of DPP-IV with compound ABT-341 as the co-crystallized (2I78.pdb) obtained from Protein Data Bank (https://www.rcsb.org/structure/2I78 accessed on 21 May 2021) was used as the starting material for MD simulations input files. The MD simulations were performed using YASARA-Structure 20.12.24 (Krieger \& Vriend, 2015) in a Google Cloud Platform (GCP) server with 16 virtual centrap processing units (CPUs), 16 GB memory and Ubuntu 16.04 LTS as the operating system. The analysis of the results of the MD simulations was performed in the same computer client used previously (Prasasty \& Istyastono, 2020) with the following additional software: (i) Windows 10 Linux Subsystem Ubuntu 20.04.02; (ii) Miniconda (https://docs.conda.io/en/latest/miniconda.html accessed on 21 May 2021); (iii) PyPLIF HIPPOS 
version 0.1.2 and its dependencies (Enade P. Istyastono et al., 2020; Enade P Istyastono et al., 2021); (iv) AutoDock Vina (Trott \& Olson, 2010); (v) AutoDockTools-prepare (https://anaconda.org/insilichem/autodocktools-prepare accessed on 21 May 2021); (vi) PLANTS docking software version 1.2 (Korb, Stützle, \& Exner, 2009); and (vii) SPORES version 1.3 (ten Brink \& Exner, 2009).

\section{Methods}

The file 2I78.pdb obtained from the Protein Data Bank was loaded to YASARA-Structure 20.12.24 in the client computer. Since only amino acids from chains A and B, and the KIQ residue in chain B used in the MD simulations, unnecessary atoms were then removed. The KIQ residue was splitted from the first object and assigned as the second object. The first object was named "dpp4", while the second object was named "ligand". The module "Clean" was then applied to all objects. Simulation cell in cubic shape of $10 \AA$ from objects 1 and 2 was then added and the "Boundary Periodic" was set for the simulations. The system was saved as "dpp4-kiq-r2md.sce". The second system, which was the system without ligand, was also prepared by deleting the second object. The second system was saved as “dpp4-apo-r2md.sce".

Both sce files were uploaded to the GCP server to be subjected independently in the MD simulations using YASARA-Structure 20.12.24 with the similar settings used previously (Enade Perdana Istyastono \& Prasasty, 2021). Compared to the settings used previously, which run for $100 \mathrm{~ns}$ with snapshots were taken at 10 ps time interval (Enade Perdana Istyastono \& Prasasty, 2021), the simulations here were run for $15 \mathrm{~ns}$ with snapshots were taken at $100 \mathrm{ps}$ time interval. The first $5 \mathrm{~ns}$ were considered equilibration time, while the subsequent $10 \mathrm{~ns}$ were considered as the production runs. The snapshots resulted from the MD simulatios were analyzed using the default macro "md_analyze.mcr", and the snapshots of the production runs were converted to pdb files using the default macro "md_convert.mcr".

Together with all the pdb files resulted from running the "md_convert.mcr" macro, the files "dpp4kiq-r2md_analysis.tab" and "dpp4-apo-r2md_analysis.tab" resulted from running the "md_analyze.mcr" macro were copied to the computer client for further analysis. The stability of the molecular systems was analysed by following suggestions by (Liu et al., 2017), while the proteinligand interactions were identified from the pdb files of the production run snapshots by employing PyPLIF HIPPOS (Enade P. Istyastono et al., 2020; Enade P Istyastono et al., 2021).

\section{RESULTS AND DISCUSSION}

The RMSD values of the backbone atoms of the DPP-IV with and without ABT-341 were obtained from the files “dpp4-kiq-r2md_analysis.tab" and “dpp4-apo-r2md_analysis.tab”, respectively. Figure 2 shows the RMSD values from 0 ns until $15 \mathrm{~ns}$. It shows that both molecular systems have reached 
equilibrium at $5 \mathrm{~ns}$ simulation time. Therefore, the subsequent $10 \mathrm{~ns}$ in the MD simulations could be considered as the production runs. According to the suggestions by Liu et al. (2017), the protein is considered as stable if the deviation of the RMSD values of the backbone atoms is less than or equal to $2 \AA$ in the last $5 \mathrm{~ns}$ from $10 \mathrm{~ns}$ production runs in MD simulations. Hence, both proteins in the two independent runs could be considered as stable, since the deviation of the RMSD values are $0.610 \AA$ and $0.997 \AA$ for DPP-IV with and without ABT-341, respectively. Notably, although both show stable molecular systems according to Liu et al. (2017), DPP-IV with ABT-341 shows more stable system compared to the one without ABT-341 (Figure 2). This indicates that the mechanism of ABT-341 as the DPP-IV inhibitors is by stabilizing the protein.

The confirmation of DPP-IV stabilization by ABT-341 (Figure 2) has lead to an emerging urgency to obtain insights of the protein-ligand interaction for further uses. Insights of protein-ligand interactions have been proven to be advantegous in drug discovery and development research projects (Deng, Chuaqui, \& Singh, 2006; Rognan, 2012; Salentin, Haupt, Daminelli, \& Schroeder, 2014; Zhao, Xie, Xie, \& Bourne, 2016). Moreover, the free and open source computational tool to assist in the proteinligand interactions identification called PyPLIF HIPPOS was made publicly available recently (Enade P. Istyastono et al., 2020). The percentage of the interactions during the MD production runs identified in this research are presented in Figure 2.

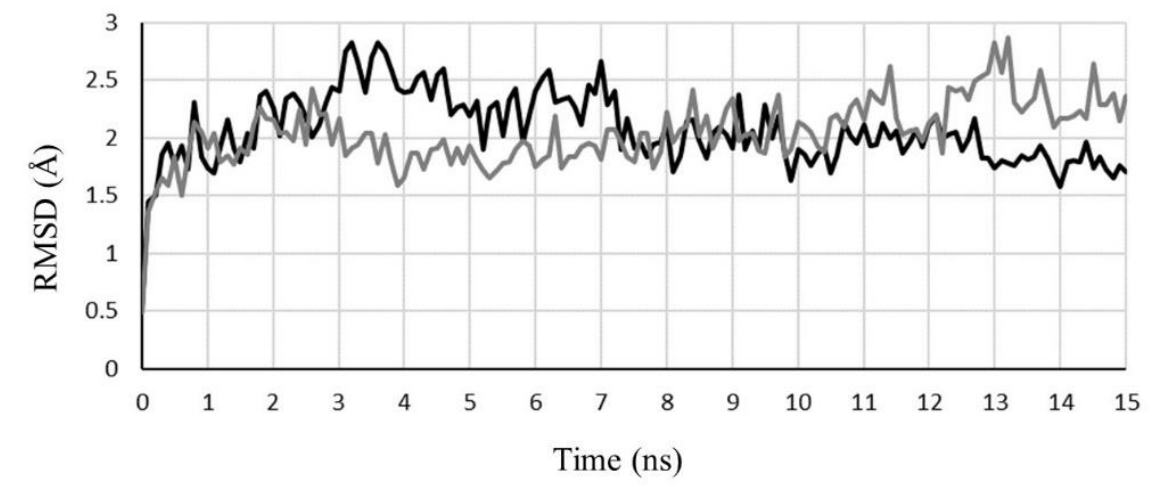

Figure 2. The curves of RMSD values of the DPP-IV backbone atoms with ABT-341 (presented in black) and without ABT-341 (presented in grey) during the MD simulations. The snapshots were taken at 100 ps time intervals. 


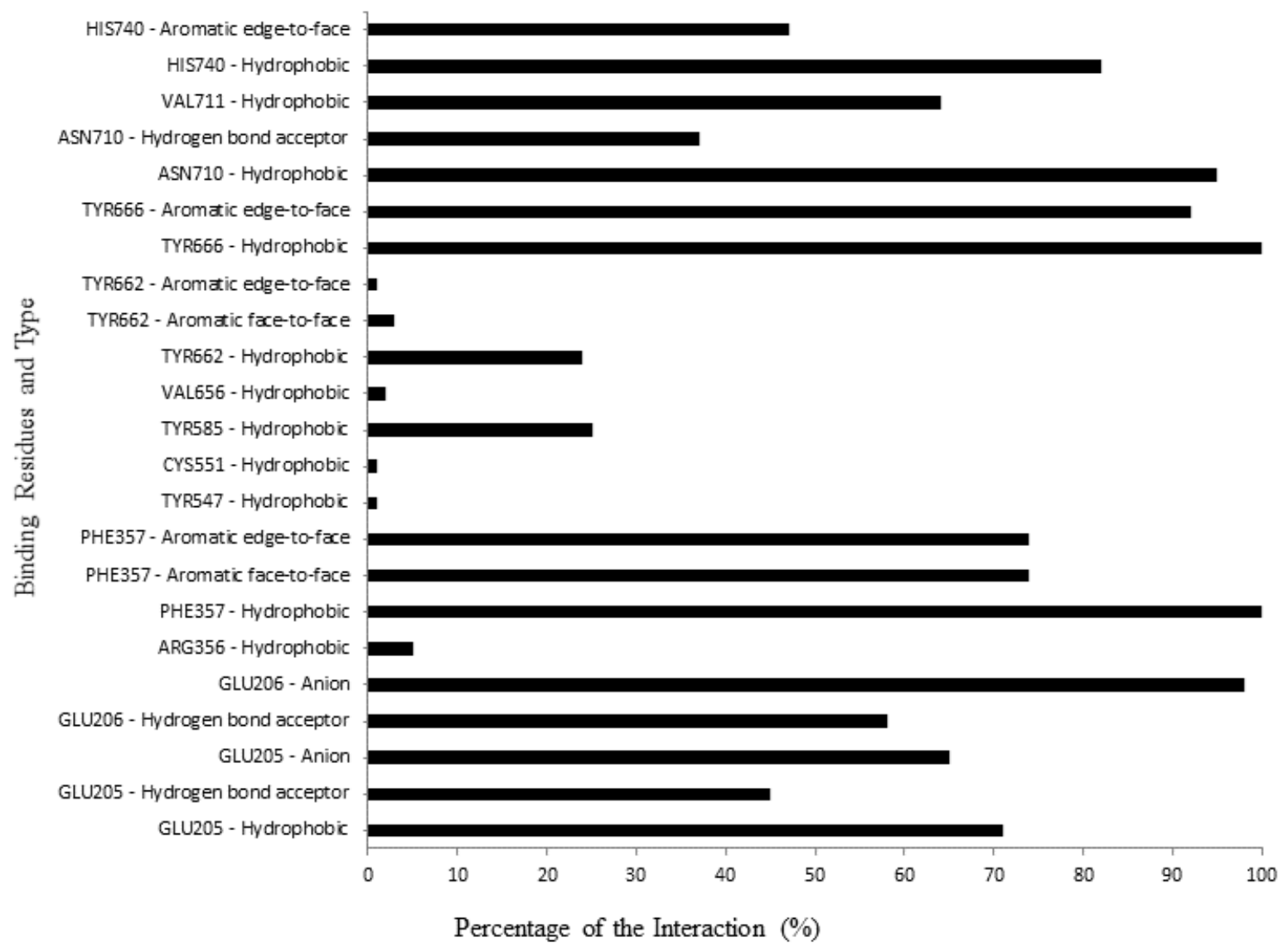

Figure 2. The percentage of all identified interaction during the MD simulations.

The software PyPLIF HIPPOS was unfortunately designed to identify only results of the docking simulations using either PLANTS or AutoDock Vina. Some workarounds were required to employ PyPLIF HIPPOS to identify protein-ligand interactions in the MD simulations presented in this article. The snapshots of the MD simulations productions were converted to pdb files using YASARAStructure in the GCP server and copied to the computer client. By employing Windows 10 Linux Subsystem Ubuntu 20.04.02 and miniconda in it to adjust the system environment, all the snapshots were experienced re-docked simulations by employing AutoDock Vina with the module "rescore_only" (Trott \& Olson, 2010). Prior to docking simulations, the complexes in pdb format were prepared by using module "splitpdb" in SPORES, and the binding pocket definitions for the docking configuration files were obtained by employing module "bind" in PLANTS. The re-docking simulations using AutoDock Vina resulted in ideal inputs for PyPLIF HIPPOS. Assisted by the binding pocket definitions, the configuration files for performing PyPLIF HIPPOS were also prepared. The "nobb" feature was used in using PyPLIF HIPPOS to avoid the identification of the backbone atoms (Enade P Istyastono et al., 2021). There were 13 binding residues identified during the MD production runs were GLU205, GLU206, ARG356, PHE357, TYR547, CYS551, TYR585, VAL656, 
TYR662, TYR666, ASN710, VAL711, and HIS740. There were two conserved interactions during the MD production runs, i.e., the hydrophobic interactions to PHE357 and TYR666. The most conserved polar interactions identified here were the ones interacting to GLU206, i.e., the ionic interaction with the residue as the anion and the hydrogen bond interactions with the residue as the acceptor. These three residues have been frequently reported as one of the suggested binding residues in DPP-IV (Fan et al., 2013). Further research similar to the one performed by Istyastono et al. (2021) could be performed to pin point the most important binding residues.

\section{CONCLUSION}

Assisted by several computational tools commonly used in drug discovery, PyPLIF HIPPOS could be employed to identify the interactions of ABT-341 to DPP-IV during MD simulations.

\section{ACKNOWLEDGEMENT}

This research was funded by Institute for Research and Community Services, Universitas Sanata Dharma (Research Grant Contract No. 013/Penel./LPPM-USD/II/2021).

\section{CONFLICT OF INTEREST}

Authors declare that there is no conflict of interest.

\section{REFERENCES}

Agrawal, P., Gautam, A., Pursnani, N., \& Maheshwari, P. K. (2018). Teneligliptin, an economic and effective DPP-4 inhibitor for the management of type-2 diabetes mellitus: A comparative study. J. Assoc. Physicians India, 66(August), 67-69.

Al-Masri, I. M., Mohammad, M. K., \& Tahaa, M. O. (2009). Inhibition of dipeptidyl peptidase IV (DPP IV) is one of the mechanisms explaining the hypoglycemic effect of berberine. J. Enzyme Inhib. Med. Chem., 24(5), 1061-1066. https://doi.org/10.1080/14756360802610761

Deng, Z., Chuaqui, C., \& Singh, J. (2006). Knowledge-based design of target-focused libraries using protein-ligand interaction constraints. J. Med. Chem., 49(2), 490-500. https://doi.org/10.1021/jm050381x

Fan, J., Johnson, M. H., Lila, M. A., Yousef, G., \& De Mejia, E. G. (2013). Berry and citrus phenolic compounds inhibit dipeptidyl peptidase IV: Implications in diabetes management. Evid. Based Complement. Alternat. Med., 2013(479505), 1-13. https://doi.org/10.1155/2013/479505

Guariguata, L., Whiting, D. R., Hambleton, I., Beagley, J., Linnenkamp, U., \& Shaw, J. E. (2014). Global estimates of diabetes prevalence for 2013 and projections for 2035. Diabetes Res. Clin. Pract., 103(2), 137-149. https://doi.org/10.1016/j.diabres.2013.11.002

Hollingsworth, S. A., \& Dror, R. O. (2018). Molecular Dynamics Simulation for All. Neuron, 99(6), 1129-1143. https://doi.org/10.1016/j.neuron.2018.08.011

Istyastono, Enade P., Radifar, M., Yuniarti, N., Prasasty, V. D., \& Mungkasi, S. (2020). PyPLIF HIPPOS: A Molecular Interaction Fingerprinting Tool for Docking Results of AutoDock Vina and PLANTS. J. Chem. Inf. Model., 60(8), 3697-3702. https://doi.org/10.1021/acs.jcim.0c00305 
Istyastono, Enade P, Yuniarti, N., Prasasty, V. D., \& Mungkasi, S. (2021). PyPLIF HIPPOS-Assisted Prediction of Molecular Determinants of Ligand Binding to Receptors. Molecules, 26(2542), 112

Istyastono, Enade Perdana, \& Prasasty, V. D. (2021). Computer-Aided Discovery of Pentapeptide AEYTR as a Potent Acetylcholinesterase Inhibitor. Indones. J. Chem., 21(1), 243-350.

Korb, O., Stützle, T., \& Exner, T. E. (2009). Empirical scoring functions for advanced protein-ligand docking with PLANTS. J. Chem. Inf. Model., 49(1), 84-96. https://doi.org/10.1021/ci800298z

Krieger, E., \& Vriend, G. (2015). New ways to boost molecular dynamics simulations. J. Comput. Chem., 36(13), 996-1007. https://doi.org/10.1002/jcc.23899

Li, N., Wang, L. J., Jiang, B., Li, X., Guo, C., Guo, S., \& Shi, D. (2018). Recent progress of the development of dipeptidyl peptidase-4 inhibitors for the treatment of type 2 diabetes mellitus. European Journal of Medicinal Chemistry, 151(10 May 2018), 145-157. https://doi.org/10.1016/j.ejmech.2018.03.041

Liu, K., Watanabe, E., \& Kokubo, H. (2017). Exploring the stability of ligand binding modes to proteins by molecular dynamics simulations. J. Comput. Aided Mol. Des., 31(2), 201-211. https://doi.org/10.1007/s10822-016-0005-2

Prasasty, V. D., \& Istyastono, E. P. (2020). Structure-based design and molecular dynamics simulations of pentapeptide AEYTR as a potential acetylcholinesterase inhibitor. Indones. J. Chem., 20(4), 953-959. https://doi.org/10.22146/ijc.46329

Rognan, D. (2012). Fragment-Based Approaches and Computer-Aided Drug Discovery. Top. Curr. Chem., 317, 201-222. https://doi.org/10.1007/128

Salentin, S., Haupt, V. J., Daminelli, S., \& Schroeder, M. (2014). Polypharmacology rescored: Protein-ligand interaction profiles for remote binding site similarity assessment. Prog. Biophys. Mol. Biol., 116(2-3), 174-186. https://doi.org/10.1016/j.pbiomolbio.2014.05.006

ten Brink, T., \& Exner, T. E. (2009). Influence of protonation, tautomeric, and stereoisomeric states on protein-ligand docking results. J. Chem. Inf. Model., 49(6), 1535-1546. https://doi.org/10.1021/ci800420z

Trott, O., \& Olson, A. J. (2010). AutoDock Vina: Improving the speed and accuracy of docking with a new scoring function, efficient optimization, and multithreading. J. Comput. Chem., 31(2), 455461. https://doi.org/10.1002/jcc

Wang, B., Sun, Y., Sang, Y., Liu, X., \& Liang, J. (2018). Comparison of dipeptidyl peptidase-4 inhibitors and pioglitazone combination therapy versus pioglitazone monotherapy in type 2 diabetes: A system review and meta-analysis. Medicine, 97(46), e12633. https://doi.org/10.1097/MD.0000000000012633

Zhao, Z., Xie, L., Xie, L., \& Bourne, P. E. (2016). Delineation of polypharmacology across the human structural kinome using a functional site interaction fingerprint approach. J. Med. Chem., 59(9), 4326-4341. https://doi.org/10.1021/acs.jmedchem.5b02041

Zheng, Y., Ley, S. H., \& Hu, F. B. (2018). Global aetiology and epidemiology of type 2 diabetes mellitus and its complications. Nat. Rev. Endocrinol., 14(2), 88-98. https://doi.org/10.1038/nrendo.2017.151 